\title{
RULES OF POLITICAL COMMUNICATION IN THE PRE-WAR SOVIET COUNTRYSIDE*
}

\author{
S. Merl \\ Bielefeld University \\ University St., 25, 33615, Bielefeld, Germany \\ (e-mail:smerl@uni-bielefeld.de)
}

\begin{abstract}
The author aims to debunk the Soviet official myth of local administration as being weak and not functioning effectively. The Soviet regime could not function in the way it pretended to, and the official picture of the economy was far from the reality though played a central role in the political discourse for the aims of legitimacy. The command economy actually functioned as a symbiosis of commands and threats 'from above' and corrupt practices of the majority of people including officials. However, this symbiosis worked quite successfully in industry ensuring impressive rates of growth, but not in agriculture and rural areas. Certainly, the kolkhoz system also combined severe control and treats with tolerance to corrupt practices condemned in the official slogans so as to save people from starvation. However, in the countryside the myth that rural administration was weak and wrongdoing proved to be the strongest basis of the regime for it corresponded to the firm conviction of rural people and traditional expectations that Stalin would pursue the paternalist rule as a "good tsar" by punishing local officials (as scapegoats) and by removing them from office (after blaming them for regime's shortcomings as incompetent managers). To keep people from protests und rebellions the rural officials' task was not only to use force and intimidation during the campaigns, but also to look away allowing the kolkhozniki from time to time to betray the state as compensation. Thus, the Soviet rural administration fulfilled its functions set by the regime, such as ensuring political communication for the aims of the faith in the legitimacy of the political rule. The author also considers a vertical channel of communication between the people and the regime - petitions to the ruler. Soviet people were encouraged to write letters including complaints to "bargain" personal dissatisfaction. Soviet peasants considered such a communication as a privilege and a part of the paternalist rule. For the regime, the most important function of such letters was preventing local protests by the timely reaction so as not to let the dissatisfaction to reach a critical level. Peasant letters became an additional means of control over rural officials that put limits to their arbitrariness.
\end{abstract}

Key words: local administration; countryside; Soviet regime; political rule; political discourse; political communication; legitimacy; command economy; corrupt practices; kolkhoz system; rural officials

The Soviet local administrations are considered to have been weak and, thus, were not functioning in the way the state or Stalin expected. The rural officials were blamed for mistakes in implementing the general policy due to their as if essential weakness. However, such an argument should be examined in the framework of implementing the state policies, and, for instance, the tasks of the local rural administration changed greatly in the early 1930s. Under the collectivization the peasants were forced to work for the state without salary, so preventing peasant rebellions became the top state priority. While at the end of 1920s rural administration was to convince peasants, from 1930s the task was to intimidate them by exercising violence and breaking the will of

* S. Merl, 2016. 
the peasantry by brute force. In other words, the rural administration were not weak and did an excellent job considering the priority aims of the regime — preventing peasant rebellions.

The dictatorship could not function in the way it pretended to. The official picture of the economy as ensuring a wealthy living to all Soviet people was far from the reality though played a central role in the political discourse for the aims of legitimacy (in Weber's terms). From the early 1930s the economy never worked only by the Stalin's commands, and the government had to accept the widespread and officially forbidden corrupt practices such as bargains with the controlling officials in the commissariats to 'soften' the plans, networks to conceal the losses of means of production by paying bribes, blat and false reports to hide and compensate for the worst shortcoming of the central orders and to achieve economic growth. Only (not always conscious or explicit) tolerance to these practices allowed Stalin to achieve economic successes and present himself as an irreplaceable arbitrator of economic interests [3; 9; 15]. The command economy actually functioned as a symbiosis of commands and threats 'from above' and corrupt practices of the majority of people including officials and directors of industrial enterprises and collective farms.

The command economy worked quite successfully in industry ensuring impressive rates of growth, but was not efficient in agriculture at all. The kolkhoz heads lacked any autonomy and did not dispose of salary funds (as in industry) to pay bribes for the needed means of production not provided by the state [18]. So, the kolkhoz system also combined severe control and threats with tolerance to corrupt practices condemned in the official slogans so as to save people from starvation. Certainly, the terror alone cannot ensure functioning of neither industry nor agriculture, especially if contradicting orders 'from above' prove that 'breaking the law' was the only way to keep up the regime $[7 ; 17]$, while respecting the law and the official slogans would have lead to sabotage and repressions.

It was essential for the regime to keep the rules of the game described above secret. The myth that rural administration was weak and wrongdoing proved to be the strongest basis of the regime in the countryside for it corresponded to the firm conviction of rural people that local officials were wrongdoing and traditional expectations that Stalin would pursue the traditional paternalist rule as a "good tsar". By punishing local officials as scapegoats and by removing them from office, Stalin succeeded in putting the responsibility for regime's shortcomings on the local rural officials as incompetent (economically ineffective) managers. However, if we take into account that under the severe hardships such as the "great famine" of 1932 - 1934 the local officials succeeded in keeping about 100 million peasants from rebelling against their miserable living conditions, the effectiveness of the local administration in securing the Soviet regime becomes evident (effective control rather than effective management of production).

After the revolution, the state apparatus consisted of locally elected soviets. The rural soviets in the 1920 s co-existed with the traditional administration of village communes, the elders and village assemblies [20]. The influence of the local soviets on the rural life besides tax collection and state campaigns was not too strong due to their rather limited tasks such as organizing the production on the land allotments of peasant 
communes. After the 1924 election campaign to the rural soviets, due to the low peasant participation the Party changed the agricultural policy to the litsom $k$ derevne (turning the face to the village), which positively affected the peasants' perception of the regime and produced incentives to increase agricultural production. Many peasants joined cooperatives and some 'middle peasants' decided to join the Party, but the trust to the Soviet regime ended in 1927 due to the state discrimination of the better-off peasants by the tax policy and disenfranchisement of the kulaks [12. P. 291-309, 411-436]

In 1928, the local rural administration turned into a means of violence and pressure that destroyed the power of traditional institutions of peasant self-government within village communes, and deprived the peasants of any possibility to express legally their will. This rupture was accompanied by the forced expropriation of grain in winter of 1927-1928 after the state introduced an additional tax to make peasants sell their grain harvest. There was no legal basis for any additional tax, therefore, the state introduced the so-called 'self-taxation' (35\% of the state agricultural tax), which was a contradiction in itself and, thus, entailed the state violence [12. P. 368-388].

In the majority of villages, the peasants saw no local needs for such a tax and refused to vote for it under the pressure of local administration. All state officials happened to stand under the threat to be removed from office if he did not want or was not able to exercise the necessary pressure on peasants or to arrest those speaking or voting against the necessary decision. To incorporate peasants into such binding decisions, the state used 'closed assemblies' governed by the rules of interpersonal communication [6; 17. P. 48 - 81] and headed by a Party official. A dissent voting was impossible due to the question wording: the voting was not about the self-taxation, but about consent or dissent with the Soviet rule. The voting against would lead to the accusations in being counterrevolutionary, arrest and often annihilation by the security forces. The self-taxation campaign destroyed the independence of village communes and became a dress-rehearsal for the forced collectivization that started in the winter of 1929 - 1930 and was imposed by the same kind of voting of the closed assemblies. Under the collectivization, the village commune finally lost its function of public opinion institution for solving peasants' problems and turned into the state means of making peasants vote for whatever the state wanted.

In implementing the state violence against peasants, the local soviets from 1928 become an effective institution within the state machine of repression for expropriating grain, collecting taxes and intimidating peasants. After the creation of kolkhozes the village commune's assembly was replaced by the meeting of kolkhoz's members that could be convoked only by the head of rural soviet or by instructors from rayon. The kolkhoz assemblies were under the state control: they had to take place at least once a year to listen to the report of the board and to elect it under the guidance of a representative of the regional Party organization. All speakers of such assemblies were to use the official speech codes to avoid arrest, and every kolkhoz member had to attend them to be bound by their decisions. The assemblies ensured unanimous voting for whatever the state demanded: shooting of "enemies of the people", signing state loans, giving all grain to the state, socialist competition in increasing milk yields per cow, finishing sow- 
ing earlier than required by the state plan, repeating the official slogans of the Party and following the official terms in any argument (even when criticizing kolkhoz administration).

To estimate whether or not the Soviet rural administration fulfilled its functions, we have to identify the tasks the regime wanted it to solve. One of the requirements was to ensure a political communication for the aims of the faith in the legitimacy of the political rule. Thus, to keep up the myth of Stalin as a good tsar, the local rural officials were to be scapegoats at the grass-root level, and to take full responsibility for all shortcomings of the official policy. The regime took advantage of the fact that the majority of rural people believed that local officials were incompetent and corrupt, and at the same time they were blamed by the higher bodies if kolkhozniki refused to accept the self-taxation, to "voluntarily" join a kolkhoz, or to support the collectivization. None of these tasks could have been fulfilled without brute force. The rural officials had no other way than to use violence and to intimidate peasants by arrests, arbitrary expropriation of farm implements, and deportation of kulak families. Some officials tried to make impossible promises such as providing tractors after creating kolkhoz, which only reinforced the economic chaos and destruction of agricultural means of production.

Although the use of violence contradicted the slogans of the regime, the plenipotentiaries 'from above' forced the local officials to use brutal terror. Although the local officials fulfilled the Party tasks the regime blamed them for not convincing peasants "to do voluntarily" what the regime wanted them to do [10. P. 113-117]. Blaming the local officials after the end of campaigns, though the officials did exactly what they were ordered to do, became a routine. At the peak of the famine in 1933, Stalin blamed the local officials and activists in Ukraine for wrongdoings [13. P. 50 - 53]. The local officials were accused of distorting the campaign slogans that supposed convincing peasants to voluntarily join the kolkhoz or give the state their last reserves of grain. The rural officials were punished or repressed even if they did cope with the state tasks for making them scapegoats for that was the regime's symbolic game. The main idea of blaming the local officials was to create confusion about regime's aims and responsibility [18]. About a third of the elected rural officials were removed every year from office mostly during the state campaigns [14. P. 90-120, 234 - 249]. Thus, the state succeeded in killing two birds with one stone: the local people were satisfied that the state punished unpopular officials, while the state was glad not to lose effective officials capable of using brute force. At the peak of state campaigns, some peasants wrote letters to Stalin accusing local officials of wrongdoings. By punishing some of his loyal officials, Stalin contributed to the credibility of the myth of being a wise father of the people. Under the state campaigns, the force was always used, while the scapegoats were chosen only after the end of the campaigns.

In 1930, the rules of the game still caused some misunderstandings and demoralization among officials, who did not understand why they were blamed for wrongdoings if they had exactly executed the orders 'from above'. However, soon rural officials got used to the rules, accepted their double functions, and realized that repressions against them in general were the result of not using brute force. The discrepancy between cen- 
tral government's orders to "convince" and the real pressure to use force against peasants is a typical example of "regressive learning" in the political communication under a dictatorship [11]. People learnt to praise the regime while breaking the official rules at the same time, that is why words and slogans lost their meaning for guiding actions. Moreover, many orders of the Party were so contradictory that could not be executed at the same time. The local officials had to choose which orders to fulfil under current circumstances to avoid repressions, and which to neglect not to entail problems. The contradiction between slogans and actions became normal under the Stalin's rule. Officials and rank and file repeated the slogans at closed assemblies, but acted differently. For instance, the state wanted to ensure a high grain harvest and at the same time to neutralize the peasantry, that is why although the Party required introducing scientific crop rotations, the local officials did not allow it for it would reduce the size of the sown area [18].

A new vertical channel of communication between the people and the regime gained striking importance for keeping up the regime - people's petitions to the ruler. Soviet people were encouraged to write letters including complaints to "bargain" personal dissatisfaction: the ruler reacted to the letters by sending orders or commissions to check the local situation, or by providing the needed help such as firewood to the elderly. As a rule, peasant letters were sent directly to Stalin or other members of the Party leadership. In most cases, the situation was checked and an answer was given [19]. Soviet peasants considered such a communication as a privilege and a part of the paternalist rule. Both sides involved kept the content of the letters confident so the regime was not obliged to discuss openly its shortcomings. For the regime, the most important function of such letters was preventing local protests by the timely reaction so as not to let the dissatisfaction to reach a critical level [17. P. 82-100]. Peasant letters became an additional means of control over rural officials that put limits to their arbitrariness: an unusual accumulation of letters against some official would lead to the inspection 'from above'. Thus, the letters valve function was preventing local rebellions and putting all responsibility for shortcomings on local officials by informing the "wise and just ruler". In such a way the regime took advantage of the widespread paternalist understanding of the rule: people addressed personally "Father" Stalin and other Soviet leaders and trusted not to institutions, but to personal relations between the heads of these institutions.

Besides playing a role of scapegoats, the rural officials had to provide the state with the agricultural products. As the state orders on deliveries of agricultural products and on taxes did not take into account the local need for survival, every year a big state campaign headed by plenipotentiaries was organized to fulfil the procurement plan. Every year the local officials had to "find" new kulaks for expropriation and "enemies of the people" to mercilessly intimidate the rest of kolkhozniki to make them fulfil their obligations to the state. As kolkhozes were interested to reduce the sown area, "taking grain" turned into a permanent fight, and local officials were to keep up a war-like situation in the countryside to meet the state requirements. The "kolkhoz system" did provide the state a huge share of the harvest, but it did not guarantee the kolkhoz enough grain for its own needs. Constant intimidation was a part of the production campaigns, of sowing, harvesting or keeping the cattle in winter, thus the rural population lost incentives 
to produce and to increase productivity in kolkhozes. To prevent peasant sabotage the officials put merciless pressure in the form of "socialist competition" to achieve the state production goals. During the campaigns, peasants' complaints were neglected not to risk achieving economic goals.

To keep people from protests und rebellions the rural official's task was not only to use force and intimidation during the campaigns, but also to look the other side to allow the kolkhozniki from time to time to betray the state as compensation [17. P. 101-109]. As the corrupt practices were a means to ensure one's survival, nearly every body in the countryside used them to provide oneself with food or other necessary goods. Stealing the "socialist property" was a basis of local survival up to the rayon level. The ordinary kolkhozniki stole from the fields for themselves as much as possible, the higher bodies used the kolkhoz assets for "gifts", bribes, and blat within their networks, the officials' corrupt practices included misusing the state property. All these corrupt practices required some willingness of compromise and "looking the other way" if people were doing something not officially permitted. "Stealing" from kolkhoz fields since August 1932 was to be punished severely; though nearly every kolkhoznik practiced it, very few were shot or punished at all [16; 17. P. 101-109].

The situation in the early 1930s lacked any calculability due to the arbitrariness of the state terror, but under the kolkhoz system, rural people regained the chance to assess the risks by grasping the rules. After grasping the rules, the kolkhozniki in their fight for survival started to take advantage of them: for instance, participating in kolkhoz work until the threshing meant that the labour days were counted for "pre-payment", and labour days after that were worthless for nothing was left for distribution at the end of the year; therefore many kolkhozniki stopped working in kolkhoz after getting the "pre-payment" [18]. The kolkhoz until the 1950s was often based on the previous village communes, i.e. its members knew each other more or less, which partly protected peasants from the state arbitrariness. The local officials had to put pressure on the local people, however, under the state campaigns, the kolkhozniki kept the possibility of collective actions in kolkhoz assemblies by blaming officials not to fulfil obligations to the state. That is why usually kolkhoz members strongly opposed merging with another kolkhoz for it would bring "outsiders" in the established local community networks, whose members sometimes acted together to defend their interests.

The Soviet regime functioning was based not only on the official orders 'from above', but also on the regional and local officials' knowing which of them to execute and which to neglect without risk. The best way to stay safe for the officials at different levels of the administrative hierarchy was report successes and to fulfil one's functions without major and visible failures. False reports (higher figures of fulfilment/production than real accomplishments) was one of the means to be praised 'from above' and avoid any forms of repressions. False reports were more secure than telling the truth for the latter inevitable lead to inspections with usually fatal consequences for local officials [3]. In the countryside, the institutional and personal control through networks was more important than the Party membership. Admission to the Party was limited in 1933 with the start of the "purging" campaigns, and only a minority of kolkhoz chairmen were Party members in the 1930s. In the early 1930s joining the Party could be a start of a career, 
while in the late 1930s those who had proved to be capable of fulfilling the tasks 'from above' were asked to become members of the Party, which positively influenced their further upward mobility and contributed to the additional control of the Party.

After destroying the still effective patriarchal system of the village, the Soviet regime was successful in organizing its active supporters from the underprivileged such as the youth lacking recognition within the traditional peasant commune, mainly women. They became team leaders, stakhanovite milk maids or tractor drivers [14. P. 182-188, 207-233], managed to be recognized by the regime, to be awarded prizes and privileges, and to lead political campaigns and village soviets' commissions.

The third apparatus of the state repression was the state security that had its informants (seksoty) in kolkhozes effectively hindering any sort of organisation 'from below': all possible ring leaders were arrested and shot before they tried to organize resistance or sabotage. Under the great terror, the intimidation in the form of arrests became widespread and included denunciations on the basis of information about "dangerous" people 'from below'.

Besides the state apparatus, there were also economic agencies: while state farms were under the control of Republican commissariats, the kolkhozes were under the control of rayon administration and of machine-tractor-stations. Every economic action in the countryside was under the party's control - preparation for the spring sowing campaign (collection of seeds, preparation of rural machinery, sowing campaign itself), preparation for the harvest, harvesting and the top-priority campaign of delivering the harvest to the state. During every campaign, the officials had to report every 5 or 10 days, and the percentages of plan fulfilling were announced in the local and central media. The campaign for winter sowing and fallow ploughing overlapped with the procurement campaigns. Besides there were political campaigns: Lenin's birthday, the soviets' elections, awarding ceremonies for the winners of the "socialist competition", 1st of May, October Revolution Day and so on.

The kolkhoz chairmen selected "their" people for administrative positions: only men for the more attractive jobs as heads of departments and brigadiers; women could be accountants and team leaders in growing industrial crops like sugar beets. A kolkhoz chairman had little opportunity to work successfully, and a removal from office was his normal fate. If he coped with his tasks in general, he had (provided he was a member of the limited cadre reserve of the Party boss) good chances to be sent to another kolkhoz or to another position at the same administrative level after the removal. There are different models of a kolkhoz chairman career: (1) was promoted, did not cope with the tasks, was removed and lost the position, sometimes was declared a scapegoat and repressed; (2) coped with the job as a successful manager and repressor, was removed from office as a scapegoat, was transferred to another position at the same level of hierarchy and stayed in the local cadre reserve.

At the beginning of the war and after the occupation of Soviet territories, the Germans obviously relied on the official descriptions of the regime (kolkhoz system and rural administration) and believed that kolkhozes strictly and ruthlessly controlled the 
peasants. The Germans trusted in official institutions while the Russians rather in personal relations, that is why the former did not expect that every year taking grain and collecting taxes would need a new fight with kolkhozniki using crude methods of intimidation. They could not anticipate to what extent the kolkhoz system was based on the corrupt practices of stealing and on false reports, and that all kolkhozniki took advantage of the rules of the game in their own interests including deceiving the state in response to the terror [1; 2. P. 114-140]. The Soviet Union had "voluntarily" supplied grain to Germany in 1939-1941 according to the Hitler-Stalin pact; but under the occupational regime, the Germans did not succeed in taking the same amounts of grain. Without an effective system of control, the occupational regime started arbitrary mass repressions in response to not having its orders executed, which only strengthened the obstruction and resistance of the local people. As a result, the agricultural supplies shrank and corrupt practices strongly increased under the German occupation lacking paternalist patterns, which were the basis of the Stalin's rule. The German rule failed to complete the task of taking agricultural products for Germany from Soviet peasants for the latter followed their own aims and were skilful in corrupt practices. The German controllers could not become a part of the local rural networks because they rationally served the German rule, while Soviet "officials" traditionally played on two fields serving both the state and peasant interests, i.e. the officials also rationally behaved in the way that would protect them best from both the state repressions and peasants' vengeance. The Germans also could not cope with the huge amount of denunciations, most of which either were false or aimed to get rid of personal or political enemies.

The Soviet rural administration was effective in putting the state pressure on peasants, in keeping them in kolkhozes and in preventing peasant rebels against the regime. The rural administration did exactly what the state demanded, i.e. functioned effectively. They provided high figures of grain, milk, meat and other agricultural products supplied to the state, though these goods were in very short supply in the village and the producers were starving. They managed to collect taxes from rural population, though their money income was almost zero. The rural officials were blamed for incompetency and wrongdoing, though that was the only means of pursuing the policy of merciless use of violence against the rural population. The agricultural production did not grow not because of failures or shortcomings of the local administration, but due to the contradictory orders 'from above'.

The rural population suffered worse exploitation than the serfs, but were aware that open resistance would lead only to arrests and executions. Therefore, they took advantage of the communication channels offered by the regime: some wrote letters to Stalin to tell about miseries and denunciate local officials responsible for them; some closed assemblies accused unpopular kolkhoz chairmen of embezzling agricultural products, and, thus, helped the state to find among its officials the best scapegoats as if responsible for the people's miseries; most peasant used corrupt practices and kept silence about them [18]. The rural population accepted the Stalin's paternalist rule to a certain extent and participated in the game of blaming local officials. It would hardly have been possible for the German occupational regime to rely on such a system. 


\section{REFERENCES}

[1] Altmann I. Opfer des Hasses. Der Holocaust in der UdSSR 1941-1945. Mit einem Vorwort von Hans-Heinrich Nolte (Zur Kritik der Geschichtsschreibung, Bd. 11). Gleichen/Zürich; 2008.

[2] Berkhoff K.C. Harvest of Despair. Life and Death in Ukraine under Nazi Rule. CambridgeL.; 2004.

[3] Berliner J.S. Factory and Management in the USSR. Cambridge; 1957.

[4] Die Stalinsche Staatsverfassung von 1936. H. Altrichter (ed.) Die Sowjetunion. Von der Oktoberrevolution bis zu Stalins Tod. Bd. 1: Staat und Partei. München; 1986.

[5] Dobronozenko G.F. Kulak kak ob'ekt social'noj politiki v 20-e - pervoj polovine 30-ch godov XX veka (na materialach Evropejskogo Severa Rossii) [Kulak as an Object of the Social Policy in the 1920's — the first half of the 1930's (on the data from the European North of Russia)]. Saint Petersburg; 2008. (In Russ.).

[6] Erren L. Stalinist rule and its communication practices: An overview. K. Postoutenko (ed.) Totalitarian Communication, Hierarchies, Codes and Messages. Bielefeld; 2010.

[7] Filtzer D. Atomization, "molecularization", and attenuated solidarity: Workers' responses to state repression under Stalin. B. Studer, H. Haumann (eds.) Stalinistische Subjekte. Individuum und System in der Sowjetunion und der Komintern, 1929-1953. Zürich; 2006.

[8] Fitzpatrick S. Stalin's Peasants. Resistance and Survival in the Russian Village after Collectivization. N.Y.; 1994.

[9] Gregory P. The Political Economy of Stalinism. Evidence from the Secret Soviet Archives. Cambridge; 2004.

[10] Kindler R. Stalins Nomaden. Herrschaft und Hunger in Kasachstan. Hamburg; 2014.

[11] Langenohl A. Afterthoughts on "totalitarian" communication. K. Postoutenko (ed.) Totalitarian Communication. Hierarchies, Codes and Messages. Bielefeld; 2010.

[12] Merl S. Der Agrarmarkt und die Neue Ökonomische Politik. Die Anfänge staatlicher Lenkung der Landwirtschaft in der Sowjetunion 1925-1928. München, Wien; 1981.

[13] Merl S. Bauern unter Stalin. Die Formierung des sowjetischen Kolchossystems 1930-1941. Berlin; 1990a.

[14] Merl S. Sozialer Aufstieg im sowjetischen Kolchossystem der 30er Jahre? Über das Schicksal der bäuerlichen Parteimitglieder, Dorfsowjetvorsitzenden, Posteninhaber in Kolchosen, Mechanisatoren und Stachanowleute. Berlin; 1990b.

[15] Merl S. Die sowjetische Kommandowirtschaft — warum scheiterte sie nicht früher? Geschichte in Wissenschaft und Unterricht, 2007;58:656-677.

[16] Merl S. Die Korruption in Russland heute - ein Vermächtnis Stalins? C. Söller, T. Wünsch (eds.) Korruption in Ost und West. Eine Debatte. Passau; 2007.

[17] Merl S. Politische Kommunikation in der Diktatur. Deutschland und die Sowjetunion im Vergleich. Göttingen; 2012.

[18] Merl S. Kak udalos' Stalinu vosprepjatstvovat' "zelenoj revoljucii” v Rossii? K voprosu o tormozhenii agrarno-technicheskogo progressa (1927-1941) [How Stalin managed to stop the "green revolution" in Russia? On the deceleration of agrotechnical progress]. Krest'yanovedenie. Teoriya. Istoriya. Sovremenost'. Uchenye zapiski 10. Moscow; 2015. (In Russ.).

[19] State Archive of the Russian Federation (GARF), fond R-5446, opisi 59, 82, 83 and 85. (In Russ.).

[20] Viola L. The Unknown Gulag. The Lost World of Stalin's Special Settlements, Oxford; 2007.

[21] Yaney G. The Urge to Mobilize. Agrarian Reform in Russia 1861-1930. Urbana; 1982. 
DOI: $10.22363 / 2313-2272-2017-17-2-192-201$

\title{
ФОРМАТЫ ПОЛИТИЧЕСКОЙ КОММУНИКАЦИИ В ДОВОЕННОЙ СОВЕТСКОЙ ДЕРЕВНЕ*
}

\author{
Ш. Мерль \\ Билефельдский университет \\ Университетская ул., 25, 33615, Билефельд, Германия \\ (e-mail: smerl@uni-bielefeld.de)
}

\begin{abstract}
Автор стремится развенчать официальный советский миф о том, что местная власть была слабой и неэффективной. Советская система по определению не могла функционировать согласно собственным лозунгам и задачам, и официальные отчеты о состоянии экономики были далеки от реалий, хотя играли важную роль в политическом дискурсе как один из инструментов легитимации советской власти. В действительности же командная экономика превратилась в симбиоз приказов и угроз «сверху» и коррупционных практик «снизу». Впрочем, этот симбиоз оказался успешным только в промышленности, которая демонстрировала убедительные темпы роста, но не в сельском хозяйстве. Колхозная система также сочетала жесткий контроль и угрозы с терпимостью к официально порицаемым коррупционным практикам, чтобы спасти население от голода. Однако в деревнях мощным фундаментом режима оказался и миф о слабости местной власти, поскольку сельские жители верили в его правдивость и традиционно ожидали проявлений патернализма от Сталина - «хорошего царя», который наказывает нерадивых чиновников (они оказались «козлами отпущения»), снимая их с должностей (после обвинения во всех недостатках режима). Задачей сельских администраций было не только использование силы и запугивание крестьян во время государственных кампаний, но и предотвращение протестов и бунтов за счет убеждения крестьян в том, что они (чиновники) могут предать государство. Таким образом, сельские администрации выполняли возлагаемые на них режимом функции, в частности, обеспечивали политическую коммуникацию, поддерживающую веру в легитимность политического строя. Автор рассматривает и вертикальный канал коммуникации между населением и режимом - петиции правителю. Власть призывала население писать письма, включая жалобы, чтобы выплеснуть накопившееся недовольство. Советские крестьяне считали подобную коммуникацию привилегий и частью патерналистского правления. Для власти главной функцией подобных писем было предотвращение протестов за счет своевременной реакции на недовольство, пока ситуация не достигла критического уровня. Крестьянские письма, тем самым, стали дополнительным инструментом контроля над сельскими чиновниками, ограничивая их произвол.
\end{abstract}

Ключевые слова: местная власть; деревня; советская власть; политический режим; политический дискурс; политическая коммуникация; легитимность; командная экономика; коррупционные практики; колхозная система; сельские чиновники

* Мерль Ш., 2016. 